International Study Group on Pancreatic Surgery (ISGPS). Surgery, 156, 3, 591-600.

8. Jang, J. Y., Kang, M. J., Heo, J. S., et al, (2014), A prospective randomized controlled study comparing outcomes of standard resection and extended resection, including dissection of the nerve plexus and various lymph nodes, in patients with pancreatic head cancer. Annals of surgery,
259, 4, 656-664.

9. Song KB, Kim SC, Lee W, Hwang DW, Lee JH, Kwon J, et al. (2020), Laparoscopic pancreaticoduodenectomy for periampullary tumors: lessons learned from 500 consecutive patients in a single center. Surgical endoscopy, 34(3): 1343-52.

\title{
NHÂN MỘT TRƯỜNG HỢP U ĐẠI BÀO CỦA XƯƠNG ĐÁ
}

\section{TÓM TẮT}

Bệnh nhân nam 45 tuổi vào viên vì đau và sưng vùng góc hàm và vùng chẩm bên trái. Kèm theo ù tai, nghe kém và liệt VII ngoại biên trái. Qua khám lâm sàng, khảo sát CT/MRI và giải phẫu bệnh. Chẩn đoán xác định là u đai bào xương. Đây là khối u lành tính nhưng có tỷ lệ tái phát cao. Không có dấu hiệu điển hình, chẩn đoán xác đinh dựa vào giải phẫu bênh Phẫu thuật là lựa chọn hàng đầu trong điêu trị u đại bào xương.

Tư khóa: u đại bào xương, u xương thái dương.

\section{SUMMARY}

\section{A CASE REPORT: GIANT CELL TUMOR OF TEMPORAL BONE}

The patient who is 45 year old man with main complaint pain and swelling in the left mandibular mastoid region. In addition, he has hearing loss, fullness of ear, facial weakness into left side. We diagnosis giant cell tumor (GCT) of temporal bone by clinical symptoms, CT/MRI and biopsy. The GCT is benign tumor, but high recurrence rate after removing tumor. It is not typical signs and symptoms. We can do the diagnosis by pathology. The surgery is the most suitable option to cure giant cell tumor of temporal bone.

Keywords: Giant cell tumor, temporal bone tumor

\section{GIỚI THIỆU}

U đại bào xương (giant cell tumor) của xương thái dương là khối u xương nguyên phát hiếm găpp, thường tìm thấy ở trung tâm cốt hóa xương của đâu xương dài, nhưng hiếm gặp hơn ở xương sọ. Những khối u này thường lành tính, nhưng tiến triển tại chổ, thường làm mòn các xương xung quanh khi nó phát triển. Cho đến hiện nay hướng đến kiểm soát và điều trị chưa đầy đủ với sự phát triển cho u đại bào xương

\footnotetext{
*Bệnh viện Chợ Rẫy

Chịu trách nhiệm chính: Ngô Văn Công

Email: congtmh@gmail.com

Ngày nhận bài: 11.5.2021

Ngày phản biên khoa họ: 5.7.2021

Ngày duyệt bài: 16.7.2021
}

Ngô Văn Công*

vùng nền sọ và thái dương [4]. Hầu hết kiến thực điều trị hiện nay xuất phát từ điều trị các tổn thương xương dài và cột sống.

\section{CA LÂM SÀNG}

Tại Khoa Tai Mũi Hong - Bệnh viện Chơ Rẫy: tháng $5 / 2021$ có bênh nhân nam 47 tuổi vào viên vì đau và sưng vùng góc hàm và vùng chẩm bên trái. Lâm sàng với một khối sung to ở vùng góc hàm và tai bên trái. Kèm theo liệt VII ngoại biên bên trái và nghe kém, ù tai bên trái. Sau khi khám lâm sàng và đánh giá $\mathrm{CT} / \mathrm{MRI}$ xương thái dương thì phát hiện khối u kích thước lớn 10x10 $\mathrm{cm}$ hủy gần toàn bộ xương đá, đến màng não phần tiểu não và xoang sigma, khối u bao cả bó mạch cảnh bên trái, khối u xấm lấn hố chân bướm hàm trái. Tiền sử đã được phẫu thuật sinh thiết được thực hiện bởi khoa ngoại thần kinh vào năm 2019 với chẩn đoán u đỉnh xương đá, và kết quả mô bênh học là u đại bào xương. Chẩn đoán xác định là u đại bào xương đá xâm lấn hố dưới thái dương. Được hội chẩn với các chuyên khoa Tai Mũi Họng, ngoại thần kinh, mach máu và ung bướu. Chuyên khoa Tai Mũi Họng sẽ phẫu thuật giảm thể tích khối u và sẽ xạ trị hổ trợ sau phẫu thuật.

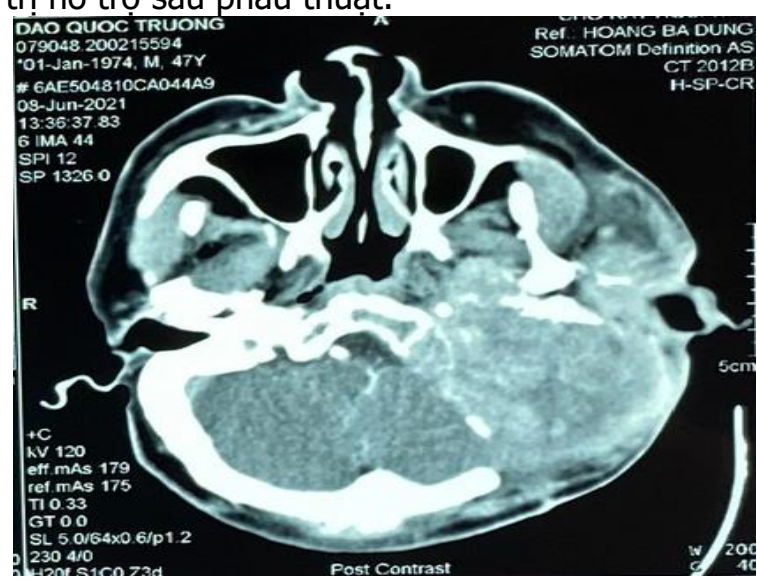

Hình 1: Khôi u hủy toàn bộ xương đá bên trái 


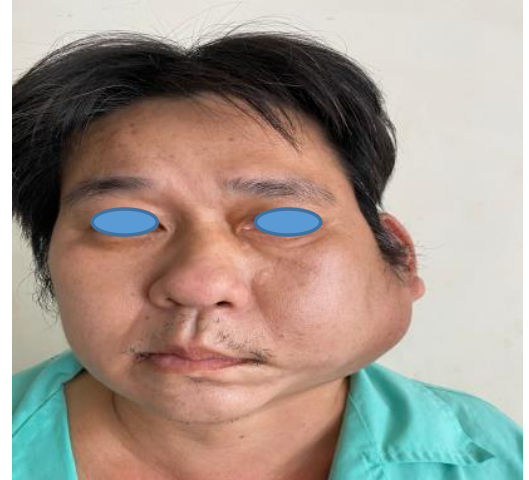

Hình 2: khôi u sưng to vùng góc hàm trái + liệt VII ngoại biên trái

\section{BÀN LUẬN}

3.1. Tổng quan về u đại bào. $U$ đại bào là một loại u nguyên phát thường tìm thấy ở xương dài. Tuy nhiên, nó hiếm gặp ở sàn sọ. Leonard và cộng sự [5] báo cáo chỉ khoảng $1 \%$ xảy ra ở vùng sọ mặt, với vùng chủ yếu là xương thái dương và xương bướm. $U$ đại bào gặp ở nam nhiêu hơn với tỷ lệ 3: 2 so với nữ, thường gặp ở độ tuổi 40 -50 tuổi [3].

Trong y văn [2], 110 trường họp u đại bào xương của sàn sọ đã được tổng kết. Vị trí khối u thường gặp ở vùng sọ mặt như sau: xương thái dương (37 trường hợp), xoang bướm (20 bệnh nhân), xương chẩm (6 trường hợp), trán (2 trường hợp) và khớp thái dương hàm (2 trường hợp). $U$ đại bào của sàn sọ thường phổ biến nhất ở trung tâm của xương thái dương.

3.2. Tiêu chuẩn chẩn đoán và triệu chứng. Không có tiêu chuẩn chẩn đoán rõ ràng. Chẩn đoán xác định dựa vào giải phẫu bệnh.

Bệnh nhân bị u đại bào xương có thể biểu hiện đa dạng triệu chứng phụ thuộc vào vị trí của nó ở vùng đầu, cổ [3]. Các triệu chứng liên quan bao gồm đau tai, đau đầu, sưng tại chổ ở xương thái dương, vùng trước tai, khớp thái dương hàm, liệt mặt,... thậm chỉ ảnh hưởng đến mắt [6].

3.3. Đặc điểm hình ảnh và mô bệnh học: U đại bào xương vùng chẩm dưới $5 \%$ các khối u lành tính, bắt nguồn từ tủy xương [1]. Về hình ảnh có những đặc điểm sau:

CT: u đại bào xương không có dấu hiệu chuyên biệt. Thường, tổn thương phá hủy và tiêu xương lan rộng. Trong một số trường hợp, hình ảnh $\mathrm{CT}$ cho thấy dạng bong bóng xà phòng (soap bubble appearance), tuy nhiên hình dạng này cũng thấy trong các nang xương phình mạch [7]. Những khối u này có mạch máu nuôi nên hầu hết tăng quang. Chẩn đoán phân biệt với u đại bào trên hình ảnh CT là các khối u, như u nguyên bào xương, sarcoma sụn, u xương di căn, nang bì, các tổn thương sợi sinh xương,..

MRI: u đại bào biểu hiện giảm tỷ trọng, khối mô mềm tăng quang không đồng nhất sau tiêm gadolinium [8]. Hủy xương quanh khối u gặp phổ biến nhưng canxi hóa thì ít gặp hơn. Những dấu hiệu này thì không đặc hiệu, vì vậy sinh thiết là cần thiết giúp chẩn đoán.

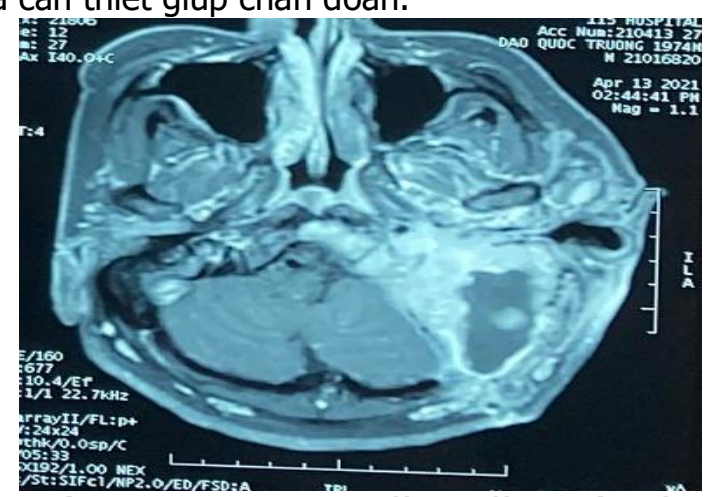

Hình 3: MRI cho thấy khối u có biên rỗ ràng, mật độ mô không đồng nhất, có mô hoại tử trung tâm giảm đậm độ

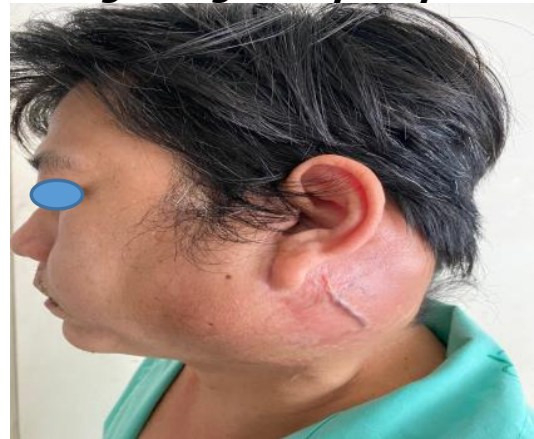

Hình 4: khôi u từ góc hàm trái lan ra xương chủm và cổ trái

\subsection{Mô bệnh họ:}

Đại thể: u đại bào được mô tả là mô mềm tăng sinh mach, dễ võ̃ và có màu nâu đến xám, cam hoặc đỏ. Màu khác biệt giúp xác định số lượng mô hoại tử và xuất huyết trong u[3].

$U$ đại bào là tên của tế bào khổng lồ nhiều nhân được phân tán qua khối u. Mỗi tế bào khổng lồ lên đến 100 nhân. Những tế bào khổng lồ này hoạt hóa các hóa chất hấp dẫn phóng thích bởi các tế bào đệm và giống với tế bào hủy xương, tái hấp thu mô xương xung quanh [6].

3.5. Điêu trị: $U$ đại bào là u lành tính với biên rõ ràng, phấu thuật cắt bỏ cho kết quả tốt và được xem là điều trị tốt nhất hiện nay. Tuy nhiên, trong nhiều trường hợp u đại bào của sàn sọ, vị trí khối u gần các cấu trúc quan trọng có thể gây khó khăn để cắt trọn hay cắt triệt để 
khối u [4]. Tỷ lệ tái phát tại chổ cho các phương pháp phẫu thuật trong u là $27 \%$, tỷ lệ tái sau cắt toàn bộ biên được báo cáo sắp xỉ $8 \%$ [7]. Tỷ lệ tái phát giảm hoàn toàn khi cắt bỏ toàn bộ khối u. Tỷ lệ tái phát dường như liên quan trực tiếp với sự lan rộng của u. Tuy nhiên, việc cắt rộng tại chổ của khối u nói chung bất tiện các u ở sàn sọ và xương thái dương do liên quan với các cấu trúc sinh tồn và biến chứng. Vai trò của xạ trị hổ trợ trong điều trị vẫn còn tranh luận. Xa trị được khuyến cáo cho khối u mà khối u đó chưa được cắt bỏ hoàn toàn. Một số quan điểm xạ trị có thể kích thích chuyển qua sarcom của u đại bào. Hóa trị và xạ trị không đóng vai trò chính trong điều trị u đại bào [6].

3.6. Tiên lượng: $U$ đại bào của sàn sọ có tỷ lệ tái phát $40-60 \%$ [6]. U đại bào là các khối u lành tính lớn và di căn trong $5-10 \%$ trường hợp, phổ biến nhất là di căn phổi [4].

\section{KẾT LUÂN}

Chẩn đoán và điều trị u đại bào của sàn sọ là một thách thức với các phẫu thuật viên Tai Mũi Họng. Chẩn đoán xác định dựa vào giải phẫu bểnh. $U$ đại bào là u lành tính nhưng có khả nắng hóa ác. Phẫu thuật hiện này vẫn là phương pháp tốt nhất trong chọn lựa điều trị.

\section{TÀI LIÊU THAM KHẢO}

1. Akyigit A, Karlidag T, Sakallioglu Ö, Polat $C_{r}$ Keles E. Giant cell tumor of bone involving the temporomandibular joint and temporal bone. J Craniofac Surg 2014; 25: 1397-9.

2. Freeman JL, Oushy S, Schowinsky J, Sillau S, Youssef AS. Invasive giant cell tumor of the lateral skull base: a systematic review, metaanalysis, and case illustration. World Neurosurg 2016; 96: 47-57.

3. Lee JA, et al. Giant cell tumor of the skull. Radiographics 1998;18(5):1295-302.

4. Iizuka $\mathbf{T}$, et al. Giant cell tumor of the temporal bone with direct invasion into the middle ear and skull base: a case report. Case Reports in Otolaryngology 2012;2012:4.

5. Leonard J, et al. Malignant giant-cell tumor of the parietal bone: case report and review of the literature. Neurosurgery 2001;48(2):424-9.

6. Tamura $\mathbf{R}$, et al. Giant cell tumor of the skull: review of the literature. J Neurol Surg Cent Eur Neurosurg 2016;77(3):239-46.

7. Matsushige T, Nakaoka M, Yahara K, Kagawa K, Miura H, Ohnuma $H$, et al. Giant cell tumor of the temporal bone with intratumoral hemorrhage. J Clin Neurosci 2008; 15: 923-7.

8. Murphey MD, et al. From the archives of AFIP. Imaging of giant cell tumor and giant cell reparative granuloma of bone: radiologicpathologic correlation. Radiographics 2001;21(5):1283-309.

\section{HIỆU QUẢ DỰ PHÒNG VÀ ĐIỀU TRI SÂU RĂNG BẰNG VÉC-NI FLUOR (5\%) VÀ KEM ĐÁNH RĂNG CÓ FLUOR TRÊN TRẺ EM 7-8 TUỔI}

\section{Nguyễn Mạnh Cường ${ }^{1,2}$, Lê Thị Thu Hà ${ }^{1,3}$, Đào Thị Dung}

\section{TÓM TẮT}

Vai trò của fluor nói chung, véc-ni fluor nói riêng trong dự phòng và điều trị bệnh sâu răng ngày càng được hiểu rõ. Nhiều nghiên cứu đã khẳng định những đóng góp của fluor trong việc làm hạ thấp tỷ lệ và mức độ trâm trọng của sâu răng trên toàn cầu. Nghiên cứu được tiển hành trên 258 trẻ em 7-8 tuổi với mục tiêu: Đánh giá hiệu quả dự phòng sâu răng bằng véc-ni fluor $5 \%$ và kem đánh răng có fluor. Đây là nghiên cứu can thiêp lâm sàng có đối chứng được tiến hành sau một nghiên cứu mô tả cắt ngang trển 1212 học sinh tại 6 Quận, Huyện tại thành phố Hà

\footnotetext{
${ }^{1}$ Viện nghiên cứu Khoa học Y Dược Lâm sàng 108

${ }^{2}$ Trường Đại học Kỹ thuật $Y$ - Dược Đà Nẵng

${ }^{3}$ Bệnh viện Trung ương Quân đội 108

${ }^{4}$ Trường Đại học Y Dược - Đại học Quốc gia Hà Nội.

Chịu trách nhiệm chính: Nguyễn Mạnh Cường

Email: dr.manhcuong@gmail.com

Ngày nhận bài: 17.5.2021

Ngày phản biên khoa họ: 6.7.2021

Ngày duyệt bài: 19.7.2021
}

Nôi. Các cháu được chon vào khám, đánh giá tình trạng bệnh sâu răng, sau đó được chia thành 2 nhóm: nhóm 1 gồm những bôi véc-ni fluor, nhóm 2 được chải kem đánh răng có fluor. Sau mỗi 6 tháng, 12 tháng và 24 tháng các cháu đước tái khám để đánh giá tình trang bệnh sâu răng. Kểt quả cho thấy, nhóm sử dụng véc-ni fluor có tỷ lệ sâu răng thấp hơn nhóm sử dụng kem đánh răng có fluor. Từ kết quả này có thể đưa ra khuyến cáo: véc-ni fluor là một trong các lựa chọn tốt để dự phòng bệnh sâu răng cho trẻ em tại cộng đồng.

Tư khóa: sâu răng, véc-ni fluor, trẻ em.

\section{SUMMARY \\ EFFICACY OF TOPICAL FLUORIDE VARNISH AND FLUORIDE TOOTHPASTE IN DENTAL CARIES PREVENTION IN CHILDREN}

The roles of fluoride in general and fluoride varnish in particular in the prevention and treatment of dental caries is increasingly understood. Many studies have confirmed the contributions of fluoride in reducing the prevalence and the severity of dental caries all over the world. The study was conducted on 258 children who is 7 years old with the objectives: To evaluate the caries prevention effects of $5 \%$ fluoride varnish and 